\title{
ANALISIS EKSPEKTASI IBU TERHADAP ANAK BAGI IBU BEKERJA DAN TIDAK BEKERJA KOTA PADANG
}

\author{
Yulhendri 1, Eka Putri ${ }^{2}$ \\ Universitas Negeri Padang ${ }^{1}$ \\ ${ }^{1}$ Email : Yulhendriunp@ gmail.com Orchid no. 0000-0002-9063-3965 \\ STKIP Panca Sakti Bekasi ${ }^{2}$
}

\begin{abstract}
Abstrak : Peran ibu dalam pendidikan anak akan membentuk watak dan sudut pandang anak tentang kehidupan. Pola asuh ibu yang bekerja dan ibu yang tidak bekerja memberikan sudut pandang yang berbeda dari perspektif anak. Ekspektasi ibu akan menentukan bagaimana ibu memposisikan peranannya dalam mendidik anak. Penelitian ini merupakan penelitian desktiptif komparatif dengan pendekatan kuantitatif. Hasil penelitian ini menunjukkan adanya pengaruh signifikan dari peran ibu terhadap pendidikan anak, persepsi anak tentang nilai dirinya terhadap ibu dan keluarganya, dan kemampuan literasi keuangan ibu berpengaruh signifikan terhadap ekspektasi ibu pada anak. Hasil penelitian ini juga menunjukkan adanya perbedaan signifikan antara ekspektasi dan kemampuan literasi keuangan ibu yang bekerja dengan ibu yang tidak bekerja. Sehingga disarankan ibu untuk meningkatkan peranan dalam pendidikan anaknya baik dalam memfasilitasi kebutuhan pendidikan anak, memotivasi anak tentang bernilainya anak bagi ibu, maupun peningkatan kemampuan literasi keuangan ibu dalam keluarga.
\end{abstract}

Kata kunci : peran ibu, nilai anak, literasi keuangan, harapan ibu

\section{ANALYSIS OF MOTHERS' EXPECTATION TOWARDS CHILDREN BY WORKING MOTHER AND NOT WORKING MOTHER IN KOTA PADANG}

\begin{abstract}
The mother's role in children education will form the character and children point of view about life. The parenting style of working and unemployed mothers provide a different perspective from the child's perspective. The expectation of mother will determine how a mother positioned her role in educating her child. This research is a comparative descriptive research using quantitative approach. The results of this research indicate the significant influence of mother's role on children's education, children's perception about her value to a mother and family, and mother's financial literacy ability significantly influence mother expectation to the child. The results of this research also indicate a significant difference between mother's expectations and financial literacy skills of the working and not working. Therefore, it is advisable for mothers to increase their role in the education of their children both in facilitating the needs of children's education, motivating children about the value of children for mothers, as well as improving the financial literacy skills of mothers in the family.
\end{abstract}

Keywords: the role of mother, the value of children, financial literation and mother expectation 


\section{Pendahuluan}

Anak merupakan output dari sebuah sistem pengasuhan dan pendidikan keluarga. Pola asuh orang tua memberikan kontribusi yang sangat besar dalam pembentukan karakter anak, terutama ibu. Ibu sebagai role model dalam keluarga, memiliki peran esensial dalam keberhasilan pendidikan anak sehingga dapat dikatakan bahwa anak merupakan refleksi dari keterampilan nurturing ibu. Gaya asuh dalam keluarga tergantung pada pola dari fungsi keluarga. Pola komunikasi dan interaksi dalam keluarga terutama antara ibu dan anak terjalin sejak anak dalam kandungan hingga akhir hayat ibu.

Orangtua dan pengaruh mereka terhadap sosialisasi anak-anak telah dianggap sebagai dasar teori psikologis. Dengan kata lain, sebagian besar penelitian mengenai perilaku pengasuhan telah diprakarsai oleh keprihatinan teoritis mengenai peran perilaku orang tua terhadap sosialisasi anak-anak. Melengkapi anak-anak dengan sarana yang diperlukan untuk menjadi individu yang sukses di masyarakat

Sebuah riset di Serbia (Marina, Prof, Todorovic, \& Dragana, 2014) yang menerapkan Model Circumplex David Olson dari Marital and Family Systems untuk menguji pola fungsi keluarga. Menurut model Circumplex, dimensi penting fungsi keluarga adalah kohesi keluarga dan fleksibilitas. Kohesi keluarga mengacu pada hubungan emosional antara anggota keluarga. Kohesi difokuskan pada bagaimana keluarga menyatukan kebersamaan dan perpisahan. Dimensi berikutnya yang sangat penting bagi fungsi keluarga adalah kemampuan beradaptasi keluarga yaitu fleksibilitas. Fleksibilitas digambarkan sebagai intensitas perubahan dalam kepemimpinan keluarga, pembagian peran dan aturan hubungan timbal balik. Definisi baru fleksibilitas keluarga adalah kualitas dan ekspresi kepemimpinan dan organisasi, distribusi peran dan gaya negosiasi. Fleksibilitas mengacu pada cara keluarga menjaga stabilitas dan perubahan.

Faktor yang berperan penting dalam implementasi pola asuh yang baik oleh ibu terhadap anak adalah harapan, harapan ibu menjadi investasi dalam kehidupan anaknya. Nilai-nilai, tradisi, dan harapan dalam keluarga merupakan faktor yang paling dominan dalam perkembangan bakat dan kepribadian anak serta dalam pengembangan kreatifitasnya sebagai manusia dewasa (Yazdani \& Daryei, 2016).

Ibu dipilih sebagai partisipan penelitian ini, karena banyak riset yang telah dilakukan menjelaskan peran dan pengaruh ibu terlalu besar dalam pendidikan dan kehidupan anakanaknya. 
Model Hoover Dempsey dan Sandler's tentang proses keterlibatan orang tua, keputusan orang tua untuk terlibat dipengaruhi oleh cara mereka membangun peran sebagai orang tua, rasa keberhasilan mereka dalam peran orang tua, dan undangan untuk berpartisipasi dari anak dan sekolah untuk terlibat. Dua konstruksi dari model Hoover Dempsey dan Sandler : kepercayaan orang tua tentang peran mereka mendukung pendidikan anak mereka dan persepsi mereka akan keberhasilan dalam melakukannya (Petrie \& Holloway, 1997).

Konstruksi peran ibu dipengaruhi oleh harapan yang dipegang oleh ibu sendiri dan orang di sekitar mereka (mis. anggota keluarga, teman, dan personil sekolah). Bagi sebagian besar ibu, peran mereka dirasakan mencakup tindakan tertentu yang menunjang proses pendidikan. Keterlibatan ibu dalam sekolah anak terjadi ketika mereka menekankan keyakinan tentang pendidikan sehubungan dengan kegiatan yang diyakini sebagai aspek yang tepat dari peran pola asuh. Hasil riset terdahulu terhadap ibu di Berkeley yang menganalisis persepsi ibu terkait keberhasilan pola asuhnya terhadap anak dan kepercayaan dirinya dalam berinteraksi dengan anak di sekolah(Petrie \& Holloway, 1997).

Peranan ibu sangat berpengaruh dalam pencapaian harapan sebagaimana yang diungkapkan oleh (Nov, Joyce, \& Weil,
2014) dalam penelitiannya bahwa terdapat beberapa faktor yang mempengaruhi harapan, yaitu dukungan sosial, kepercayaan religius dan kontrol. Dukungan sosial berupa lingkungan keluarga, teman sebaya dan lingkungan sekitar anak. Dukungan lingkungan keluarga terutama ibu sebagai makhluk terdekat dengan anak akan berpengaruh besar pada keberhasilan pendidikan anak yang nantinya juga akan berpegaruh pada pencapaiaan harapan ibu tersebut.

Sehubungan dengan itu terdapat pengaruh yang signifikan dari lingkungan keluarga pada perkembangan bakat anak dan prestasi serta perkembangan kepribadian anak. Gaya asuh yang diterima anak akan memberikan ruang emosional bagi anak dan membuat mereka menyukai tantangan, dan memberi peluang bagi anak berbakat untuk meraih prestasi optimal (Yazdani \& Daryei, 2016).

Hubungan antara orang tua dan anak tergantung terutama pada sikap dan perilaku orangtua. Oleh karena itu orang tua adalah model identifikasi bagi anak-anak mereka dalam hal sikap dan perilaku. Faktor yang mempengaruhi sikap orang tua adalah fungsi keluarga (Attitudes, Demİrcİoğlu, \& Ömeroğlu, 2014).

Hubungan antara anak dan orang tua bersifat timbal balik, artinya perilaku anak akan mempengaruhi harapan orang tua 
terhadap anak, begitu pula sebaliknya, perilaku anak akan dipengaruhi oleh sikap, harapan dan perlakuan orang tuanya. Hal ini semakin mempertegas bahwa keluarga terutama ibu memiliki peran penting dalam keberhasilan pendidikan anak karena masing-masing ibu memiliki harapan tersendiri terhadap anaknya kelak. Sebuah riset oleh Kochanska dan Knaack menjelaskan tingkatan hubungan timbal bailk atau responsif dijadikan sebagai standar penting yang menentukan kualitas hubungan ibu dan anak dan merupakan salah satu faktor yang membedakan hubungan mereka dari individu lain (Knaack, 2003). Bahkan adanya komunikasi timbal balik yang baik antara ibu dan anak tersebut merupakan tujuan utama dari berhasilnya kehidupan bermasyarakat. Anak yang selalu terlibat dalam sistem komunikasi responsif yang baik dengan ibunya lebih cenderung menerima nilai-nilai dari orang tuanya terutama ibu (Kochanska \& Clark, n.d., 1997).

Keberhasilan pendidikan sebagai sarana pencapai harapan menjadi perhatian penting bagi seorang ibu. Untuk mencapai pendidikan anak yang berhasil, ibu akan berusaha memberikan yang terbaik kepada anak. Peran ibu dalam pendidikan anak dapat berupa sebagai fasilitator, pendidik, contoh teladan dan motivator.
Sebuah teori dirancang oleh HooverDempsey menggambarkan bahwa proses keterlibatan orang tua dalam keberhasilan pedidikan anak dipengruhi oleh perspektif orang tua, prilaku, dan konstruk psikologis (Hoover-dempsey \& Sandler, 1997). Salah satu faktor penunjang keberhasilan pendidikan anak adalah terjalinnya komunikasi yang baik dan efektif antara ibu dan anak. Komunikasi yang baik dan efektif tersebut dapat dibangun dengan cara ibu meluangkan waktu bersama anak dan menjamin anak dapat terbebas dari stres karena rutinitas yang dijalaninya setiap hari dan dapat menciptakan suasana hati yang gembira.

Ibu yang selalu memberikan nasehat berupa motivasi kepada anak akan mempengaruhi perasaan dan cara berpikir anak sehingga anak akan merasa ada yang peduli dan perhatian kepada dirinya dan menjadi dorongan kuat untuk bersikap menjadi lebih baik demi mencapai prestasi yang membanggakan.

Selanjutnya nilai anak bagi orang tua memiliki nilai yang tinggi dalam kehidupan keluarga bahkan melebihi nilai harta kekayaan. Anak merupakan harapan serta kebahagiaan yang tidak ternilai harganya bagi orang tua. Sebuah riset di Amerika menyatakan nilai anak bagi orang tua meskipun ada sedikit perbedaan antara pria dan wanita atau antara orang tua dengan 
frekuensi nilai umumnya berbeda karena ada orang tua yang memberikan tanggapan spesifik. Ada beberapa aspek yang dilihat untuk melihat nilai anak bagi orang tua, pertama fokus pada kebutuhan akan makna atau pengembangan kehidupan, dan kedua focus pada konsep keabadian atau kelanjutan kehidupan setelah seseorang meninggal, ketiga keterlibatan secara aktif dalam peran pola asuh, keempat bahwa orang tua memiliki rasa berhasil, bangga dan tertantang dalam membesarkan anaknya dan mengamati kemudian memiliki harapan atas kinerjanya (Hoffman, Thornton, \& Jean, 1978).

Gambaran riset-riset terdahulu di atas mengungkapkan nilai anak bagi orang tua dalam kehidupan dapat diketahui antara lain dari adanya kenyataan bahwa anak menjadi tempat bagi orang tua mencurahkan kasih sayang. Di samping itu anak juga merupakan sumber kebahagiaan keluarga, terkadang anak dijadikan pertimbangan oleh orang tua untuk membatalkan niatnya bercerai. Terhadap anak nilai-nilai didalam keluarga di sosialisasikan dan harta kekayaan keluarga diwariskan. Anak juga menjadi tempat orang tua untuk mewujudkan berbagai harapan.

Nilai anak menjadi kriteria utama dalam mencapai tujuan sehingga menentukan keberlanjutan seluruh keputusan dan tindakan orang tua dalam membesarkan anak. Ibu menilai bahwa keberadaan anak akan menjamin keberadaan orang tua di hari tua, dapat memberi hiburan, menghindari kesendirian, menjadikan orang tua lebih bertanggung jawab (Hartoyo, Latifah dan Mulyani, 2011). Temuan tersebut menunjukkan bahwa anak dinilai memberikan manfaat psikologis, ekonomi dan jaminan dihari tua. Penilaian atau anggapan tersebut akan mempengaruhi perlakuan ibu terhadap anak. Ibu yang menganggap anak berharga akan mengajarkan dan memberikan perlakuan baik kepada anak yang akan berdampak kepada perilaku anak nantinya karena perlakuan tersebut akan menjadi contoh bagi anak dalam bersikap.

Ibu yang menilai anak dapat memberikan manfaat ekonomi dan jaminan hari tua akan mulai memperhatikan pendidikan anak, dengan mencukupi semua kebutuhan anak dan melengkapi fasilitas penunjang pendidikan anak. Hal ini dilakukan dengan harapan anak tersebut dapat memberikan perhatian dan jaminan hari tua sewaktu orang tua tidak lagi mampu mengurus dirinya sendiri dan tidak berpenghasilan lagi.

Berdasarkan hasil pengamatan penulis terhadap para ibu di Kelurahan Anduring Kecamatan Kuranji Kota Padang terlihat bahwa setiap anak memiliki nilai masingmasing bagi para ibu. Dalam penerapannya, ada sebagian anak yang merasa penilaian tersebut terkesan berlebihan bahkan 
dianggap sebagai obsesi oleh anak terhadap dirinya. Hasil wawancara penulis dengan beberapa anak menunjukkan bahwa penilaian ibu akan arti keberadaan dirinya dalam keluarga membuat perlakuan ibu menjadi sikap yang berlebihan sehingga membuat anak tidak nyaman bahkan tertekan, takut jika ia tidak mampu mencapai penilaian yang telah diberikan terhadapnya. Sikap tidak nyaman atau tertekan anak ditunjukkan dengan sikap berontak dan lebih suka menyendiri. Namun di lain pihak, ada anak yang menganggap penilaian tersebut merupakan sebuah penghargaan yang mendorong dirinya untuk jadi seperti yang dinilaikan dan berusaha membanggakan orang tuanya.

Dalam mencapai harapan terhadap anak, ibu tidak hanya berperan sebagai pendidik atau penilai anak saja tetapi ibu juga harus memiliki kecakapan dalam merencanakan keuangan keluarga yang nantinya akan berdampak pada masa depan anak. Rosaline (2013) menjelaskan bahwa dalam membuat perencanaan keuangan dibutuhkan literasi keuangan.

Literasi keuangan sudah menjadi indikator penting dalam kehidupan, tidak hanya bagi keluarga dan pelaku ekonomi profesional. Institusi keuangan, komunitas pinjaman bagi mahasiswa, pelaku profesional ekonomi, dan pendidik telah menyadari bahwa pendidikan pengelolaan keuangan pribadi merupakan prioritas saat ini (Cude, Lawrence, \& Agcenter, 2006). Riset Lyons (2003) mengungkapkan bahwa satu dari tiga mahasiswa mengatakan bahwa literasi keuangan yang baik mempengaruhi kemampuan menyelesaikan gelar sarjana (Lyons, 2004).

Mengelola keuangan dengan cara yang lebih baik bukan hanya kewajiban bagi perusahaan atau badan usaha. Namun, Individu di rumah tangga juga memiliki diwajibkan untuk mengelola keuangan dengan baik agar bisa lebih makmur di masa depan. Dengan Pengelolaan keuangan yang baik dan benar, maka individu dalam rumah tangga akan terhindar dari kesulitan keuangan. Dengan mengatur arus keuangannya, orang-orang di rumah tangga akan dapat menjaga keseimbangan antara pendapatan dan pengeluaran yang dibutuhkan (Dwiastanti, 2015).

Melihat kenyataan biaya pendidikan dari tahun ke tahun yang mengalami peningkatan, dibutuhkan kemampuan ibu dalam membuat perencanaan keuangan yang akan sangat bergantung pada pengetahuan ibu dalam memilih instrumen produk jasa keuangan. Fakta di lapangan, sebagaimana yang dikemukakan Otoritas Jasa Keuangan bahwa masih banyak konsumen atau masyarakat indonesia yang less literate atau not literate sehingga diperlukan peningkatan literasi keuangan sebagai salah satu cara 
meningkatkan pengetahuan, keyakinan, dan keterampilan, konsumen atau masyarakat agar konsumen dan masyarakat dapat menentukan produk dan jasa keuangan yang sesuai dengan kebutuhan mereka, memahami dengan benar manfaat dan resikonya, mengetahui hak dan kewajiban serta meyakini bahwa produk dan jasa keuangan yang dipilih tersebut dapat meningkatkan kesejahteraan mereka.

Pemahaman mengenai instrumen produk dan jasa keuangan tersebut akan mempermudah ibu untuk membuat perencanaan keuangan pada pengalokasian dana pendidikan anak (www.ojk.go.id). Ibu yang memiliki pengetahuan dan keterampilan dalam mengelola keuangan akan mampu mengalokasikan dana pendidikan anak dengan baik sehingga pendidikan anak dapat berjalan dengan lancar. Pengelolaan keuangan dilakukan ibu dengan harapan anak dapat mencapai pendidikan yang lebih tinggi dan menjadi investasi jangka panjang yang dapat ia nikmati dihari tua nanti.

Gerakan emansipasi wanita telah membawa perubahan yang besar pada peran perempuan di sektor publik. Sehingga banyak perempuan termasuk diantaranya adalah wanita yang telah berstatus menikah untuk masuk ke dunia kerja. Berdasarkan hasil survei Angkatan Kerja Nasional/ Sakernas tahun 2016 mengenai tingkat partisipasi angkatan kerja diketahui sebanyak $52,6 \%$ dari angkatan kerja indonesia merupakan perempuan. Data tersebut memberikan gambaran besarnya jumlah perempuan yang bekerja termasuk didalamnya perempuan yang sudah menikah sehingga memiliki peran ganda, sebagai istri dan ibu sekaligus sebagai wanita bekerja.

Sebuah riset di Amerika mengevaluasi apakah orang yang sulit untuk memahami lingkungan keuangan mereka juga kurang cenderung mengumpulkan kekayaan. Pendekatan ini menguji hubungan antara akumulasi kekayaan dan melek finansial, yang dengannya berarti memiliki kemampuan untuk memproses informasi ekonomi dan membuat keputusan tentang keuangan rumah tangga (Behrman et al., 2015).

Sejalan dengan melek finansial dalam rumah tangga, terjadi pergeseran peran ibu yang awalnya tidak bekerja menjadi bekerja sehingga akan berdampak pada pendidikan anaknya. Anak yang biasanya mendapat perhatian penuh dari ibu yang biasa di rumah mengurus dirinya dan keluarga akan kehilangan perhatian tersebut jika ibunya bekerja. Anak yang biasanya kekurangan fasilitas belajar karena ketidakmampuan keuangan keluarga dalam mencukupi kebutuhan tersebut teratasi dengan adanya penghasilan tambahan dari ibu bekerja. 
Sebuah riset di Inggris menjelaskan suatu analisis yang berkaitan secara khusus dengan efek pekerjaan ibu pada hasil kognitif anak di masa kecil. Pekerjaan ibu mungkin memberi dampak pada dimensi lain seperti perilaku dan sosioemosional, di masa kanakkanak dan di kemudian hari (Gregg, Washbrook, Propper, \& Burgess, 2005).

Banyak dampak yang ditimbulkan akibat bekerjanya seorang ibu untuk mencari nafkah. Kenakalan remaja yang sering terjadi merupakan akibat yang ditimbulkan oleh ketidakharmonisan dan ketidakmampuan keluarga itu sendiri dalam menciptakan iklim komunikasi, di satu sisi orang tua yang karena kesibukannya mencari nafkah hidup keluarganya kurang memberikan waktu untuk berkomunikasi secara efektif kepada anak-anaknya. Di sisi lain anak-anak enggan berkomunikasi secara efektif kepada orang tuanya, disebabkan karena iklim komunikasi dalam keluarga yang kurang kondusif, padahal keluarga merupakan sarana atau ladang yang paling strategis untuk menyemaikan benih-benih keagamaan dan nilai-nilai kebaikan. Dalam konteks ini, orang tua sebenarnya mempunyai peranan yang besar serta strategis dalam mentradisikan nilai-nilai kebaikan yang bersumber dari ajaran agama itu yang memungkinkan nilai-nilai kebaikan tersebut dapat ditanamkan ke dalam jiwa anak-anak tersebut (Rimporok, 2015).
Namun hasil penelitian Fitria (2016) mengenai peran ibu yang bekerja terhadap pendidikan anak menunjukkan bahwa anakanak ibu bekerja tetap berprestasi walaupun ibu sibuk bekerja. Hal ini terjadi karena ibu bekerja mencukupkan semua fasilitas penunjang belajar dan memotivasi anak agar tetap berprestasi.

Dalam hal menilai anak, perlakuan ibu tidak bekerja akan berbeda dengan ibu bekerja sesuai dengan budaya dan harapan ibu tersebut terhadap anak. Dari segi budaya, Ibu yang menganut sistem kekerabatan matrilenial akan menilai kehadiran anak perempuan lebih berharga dibandingkan anak laki-laki berbeda dengan ibu yang menganut sistem kekerabatan patrilenial yang menilai kehadiran anak laki-laki lebih berharga dibandingkan dengan anak perempuan. Dari segi ekonomi, dimana anak dinilai dapat memberikan mamfaat ekonomi dan jaminan hari tua akan mulai memperhatikan pendidikan anak, dengan mencukupi semua kebutuhan anak dan melengkapi fasilitas penunjang pendidikan anak karena pendidikan di anggap investasi jangka panjang yang dapat ia nikmati di hari tua nanti. Dengan adanya penilaian tersebut, tidak jarang anak merasa dibeda-bedakan dan kadang perlakuan yang diberikan oleh ibu juga berbeda sesuai dengan harapan ibu tersebut terhadap anak. 
Dalam hal literasi keuangan, ibu bekerja akan berbeda pula dengan ibu tidak bekerja. Sesuai dengan hasil penelitian Rosaline (2013) mengenai alokasi pendapatan dan literasi keuangan menunjukkan bahwa ibu bekerja memiliki tingkat literasi keuangan yang tinggi dibandingkan dengan ibu tidak bekerja. Hal ini di sesuaikan dengan pengetahuan dan keterampilan masing-masing ibu dimana ibu tidak bekerja hanya berada di lingkungan keluarga sehingga pengetahuan dan keterampilannya hanya terbatas di sekitar lingkungan keluarga saja. Berbeda dengan ibu bekerja yang berada pada dunia kerja akan menjadikan pola pikirnya lebih terbuka dan memiliki wawasan yang luas dan dinamis mengenai literasi keuangan yang baik terutama dalam pengelolaan keuangan untuk pendidikan anak.

Dari beberapa riset yang telah dilakukan peneliti sebelumnya, maka penulis ingin melihat sejauh mana pengaruh peran ibu dalam pendidikan anak, nilai anak dalam keluarga dan literasi keuangan terhadap ekspektasi anak dan apakah peran ibu dalam pendidikan, nilai anak dalam keluarga dan literasi keuangan ibu bekerja lebih tinggi dibandingkan ibu tidak bekerja.

\section{METODE PENELITIAN}

Penelitian dilakukan dengan menggunakan metode deskriptif komparatif dengan pendekatan kuantitatif. Data yang dipakai dalam penelitian ini adalah data primer dan sekunder. Sumber data sesuai yang diperlukan. Data primer bersumber dari angket yang diisi oleh ibu bekerja dan tidak bekerja di Kelurahan Anduring Kecamatan Kuranji Kota Padang. Sedangkan data sekunder bersumber Badan Pusat Statistik Kota padang. Pengambilan sampel dilakukan dengan teknik Purposive Sampling dan untuk menentukan ukuran sampel peneliti menggunakan rumus William G. Cochran maka di peroleh sampel sebanyak 98 orang diantaranya 49 orang ibu bekerja dan 49 orang ibu tidak bekerja. Teknik pengumpulan data dengan angket dan observasi. Teknik analisis data menggunakan analisis regresi linear berganda untuk melihat pengaruh variabel bebas terhadap variabel terikat dan uji beda untuk melihat perbedaan dua rerata antara ibu bekerja dan tidak bekerja.

\section{HASIL PENELITIAN}

Tingkat ketercapaian responden untuk variabel ekspektasi ibu terhadap anak adalah sebesar 73,20 hal ini bermakna bahwa ekspektasi terhadap anak berkategori cukup, karena berada pada rentang 65\%-79\%. Tingkat ketercapaian responden untuk variabel peran ibu dalam pendidikan adalah sebesar 76,16 hal ini bermakna bahwa peran ibu dalam pendidikan berkategori cukup 
baik, karena berada pada rentang $61 \%-80 \%$.

Tingkat ketercapaian responden untuk variabel nilai anak dalam keluarga adalah sebesar 77,93\% hal ini bermakna bahwa nilai anak dalam keluarga berkategori cukup baik, karena berada pada rentang 65\%-79\%. Tingkat ketercapaian responden untuk variabel literasi keuangan adalah adalah sebesar 75,32 hal ini bermakna bahwa literasi keuangan berkategor cukup baik, karena berada pada rentang 65\%-79\%. Berikut tabel koefisien regresi dari ibu yang bekerja dan ibu tidak bekerja.

Tabel 1. Koefisien Regresi ibu bekerja dan tidak bekerja

\begin{tabular}{clcc}
\hline No & \multicolumn{1}{c}{ Variabel } & \multicolumn{2}{c}{ Koefisien regresi } \\
& & Bekerja & $\begin{array}{c}\text { Tidak } \\
\text { bekerja }\end{array}$ \\
\hline 1 & (Constant) & 4,848 & 1,525 \\
2 & Peran dalam pendidikan anak & 0,153 & 0,271 \\
3 & Nilai anak dalam keluarga & 0,353 & 0,210 \\
4 & Literasi keuangan & 0,192 & 0,197 \\
\hline Sumber: hasil olahan data primer $\mathbf{2 0 1 7}$
\end{tabular}

Pada ibu tidak bekerja, peran ibu dalam pendidikan memberi pengaruh terbesar dalam pencapaian ekspektasi terhadap anak. Dimana nilai koefisien regresinya sebesar 0,271. Hal ini berarti dalam pencapaian ekspektasi terhadap anak, ibu tidak bekerja lebih menekankan perannya sebagai ibu keluarga yang memfasilitasi kebutuhan, mendidik, menjaga, merawat dan memotivasi anak agar tetap berprestasi karena waktu ibu lebih banyak dihabiskan bersama keluarga terutama anak dirumah.
Nilai anak dalam keluarga menjadi pengaruh kedua dalam pencapaian ekspektasi terhadap anak dengan nilai koefisien regresi sebesar 0,210. Hal ini berarti dalam pencapaian ekspektasi, ibu tidak bekerja menilai keberadaan anak dapat menjadi investasi jangka panjang yang dapat mengangkat status sosialnya kelak dengan memperhatikan pendidikan anak mulai sejak dini.

Pada ibu tidak bekerja, Literasi keuangan memberi pengaruh sebesar 0,197. Hasil ini menjadikan literasi keuangan memberikan pengaruh terendah dalam pencapaian ekspektasi terhadap anak. hal ini menunjukkan bahwa kemampuan dalam mengelola keuangan keluarga tidak dianggap penting oleh ibu tidak bekerja sehingga banyak dari ibu tidak bekerja yang kurang mampu bahkan ada tidak mampu mengelola keuangannya dengan baik dan benar.

Pada ibu bekerja, nilai anak dalam keluarga memberi pengaruh terbesar dalam pencapaian ekspektasi terhadap anak. Dimana nilai koefisien regresinya sebesar 0,353 . Hal ini berarti dalam pencapaian ekspektasi terhadap anak, ibu bekerja lebih menekankan akan arti penting seorang anak dalam keluarga. Nilai anak bagi ibu bekerja menjadi kretaria utama dalam mencapai tujuan sehingga menentukan keberlanjutan seluruh keputusan dan tindakannya dalam membesarkan anak. misalkan anak dianggap 
dapat menjadi investasi jangka panjang yang sangat baik yang dapat meningkatkan status sosialnya kelak dengan memperhatikan pendidikan anak mulai sejak dini.

Literasi keuangan menjadi pengaruh kedua dalam pencapaian ekspektasi terhadap anak dengan nilai koefisien regresi sebesar 0,192 . Hal ini berarti dalam pencapaian ekspektasi terhadap anak, kemampuan dalam mengelola keuangan sudah dianggap penting oleh ibu bekerja. Dimana ibu yang memiliki pemahaman dalam mengelola keuangan akan mampu mengalokasikan dana pendidikan anak dengan baik sehingga pendidikan anak dapat berjalan dengan lancar. Pengelolaan keuangan dilakukan ibu dengan harapan anak dapat mencapai pendidikan yang lebih tinggi dan menjadi investasi jangka panjang yang dapat ia nikmati dihari tua nanti. Dimana semakin baik pengelolaan keuangan pendidikan anak, semakin tinggi harapan ibu tersebut terhadap anak.

Pada ibu bekerja, peran ibu dalam pendidikan memberi pengaruh sebesar 0,153. Hasil ini menjadikan peran ibu dalam pendidikan memberikan pengaruh terendah dalam pencapaian ekspektasi terhadap anak. Ibu bekerja yang harus menjalankan peran ganda sebagai ibu keluarga dan wanita pekerja membuat waktu dan perhatiannya terhadap anak menjadi berkurang sehingga peran ibu bekerja dalam pendidikan anak tidak begitu tampak jelas.
Hasil uji hipotesis menjelaskan bahwa terdapat pengaruh yang signifikan dari semua variabel independen terhadap variabel dependen pada taraf signifikansi 0,000. Untuk indikator ibu bekerja dan ibu tidak bekerja, dilakukan komparasi antara keduanya. Hasil penelitian menunjukkan tidak adanya perbedaan yang signifikan antara ibu bekerja dengan ibu tidak bekerja dalam hal peran ibu dalam pendidikan anak, nilai anak bagi ibu, dan kemampuan literasi keuangan ibu.

\section{Diskusi}

Hasil penelitian ini menemukan bahwa peran ibu dalam pendidikan berpengaruh signifikan terhadap ekspektasi anak. Artinya semakin tinggi peran ibu dalam pendidikan anak maka semakin tinggi pula ekspektasi ibu tersebut terhadap anak. Sebaliknya semakin rendah peran ibu dalam pendidikan anak maka semakin rendah pula ekspektasi ibu tersebut terhadap anak.

Peran yang diberikan ibu dapat berupa sebagai fasilitator, pendidik, contoh teladan maupun sebagai motivator yang dapat mempengaruhi perasaan dan cara berpikir anak. Kebutuhan pendidikan anak yang selalu terpenuhi, anak selalu diarahkan dan diawasi dalam bersikap, ibu selalu mendengarkan dan menunjukkan sikap baik serta ramah kepada anak, dan ibu selalu memberi dorongan agar tidak mudah 
menyerah dalam belajar akan membuat anak merasa ada yang peduli dan perhatian kepada dirinya dan menjadi dorongan kuat untuk bersikap menjadi lebih baik demi mencapai prestasi yang membanggakan sehingga pendidikan yang dijalani anak dapat berhasil dan ekspektasi yang diinginkan dapat tercapai.

Temuan ini diperkuat oleh pendapat Hartini (2011:13-14) yang menyatakan bahwa keberhasilan setiap aktivitas individu dipengaruhi oleh adanya motivasi yang kuat baik dari dalam diri maupun dari luar individu tersebut, sebaliknya aktivitas yang tidak disertai dengan motivasi akan sulit berhasil dalam mencapai tujuan yang diharapkan sehingga motivasi dari ibu menjadi peran yang sangat penting dalam mencapai tujuan yang diharapkan. Gunarsa (Gunarsa, 2006:144) juga mengungkapkan bahwa hubungan antara anak dan orang tua bersifat timbal balik, artinya perilaku anak akan mempengaruhi harapan orang tua terhadap anak, begitu pula sebaliknya, perilaku anak akan dipengaruhi oleh sikap, harapan dan perlakuan orang tuanya. Hal ini semakin mempertegas bahwa keluarga terutama ibu memiliki peran penting dalam keberhasilan pendidikan anak karena masing-masing ibu memiliki harapan tersendiri terhadap anaknya kelak.

Selanjutnya terkait dengan partisipasi peran orang tua terutama ibu dalam pendidikan anak juga dinyatakan oleh (Georgiou, 2007) bahwa komunikasi dan aspirasi orang tua paling efektif dan memiliki efek jangka panjang langsung kepada siswa. Partisipasi orang tua tampaknya menjadi yang paling efektif untuk faktor keterlibatan orang tua. Faktor keterlibatan orang tua berupa komunikasi dan aspirasi menunjukkan efek langsung yang konsisten dari awal ke pertumbuhan akademik berikutnya. Hal ini menunjukkan bahwa peran orang tua terutama ibu sebagai makhluk terdekat dengan anak menjadi salah satu faktor penentu keberhasilan pendidikan anak yang berlangsung jangka panjang dari awal pendidikan anak sampai ketahap selanjutnya karena setiap orang tua atau ibu memiliki cita-cita dan harapan untuk keberhasilan tujuan pada masa yang akan datang.

Hasil penelitian lebih lanjut menemukan bahwa rerata peran ibu bekerja lebih tinggi dibandingkan rerata peran ibu tidak bekerja dan uji beda antara keduanya menunjukkan perbedaan yang tidak signifikan. Hal ini berarti bahwa dalam pendidikan anak, ibu bekerja lebih berperan dibandingkan ibu tidak bekerja. Pada ibu bekerja, dunia kerja akan menjadikan pola pikir dan wawasan ibu tersebut menjadi lebih luas sehingga pengetahuan akan pendidikan yang baik untuk anak akan lebih luas pula. Dengan adanya tambahan pemasukan 
keluarga dari penghasilan ibu bekerja dapat digunakan untuk memenuhi kebutuhan pendidikan anak sehingga anak tidak pernah kekurangan dan lebih termotivasi untuk tetap berprestasi. Berbeda dengan ibu tidak bekerja yang hanya berada di lingkungan keluarga sehingga pengetahuan dan keterampilannya hanya terbatas di sekitar lingkungan keluarga saja dan tidak ada tambahan penghasilan yang dapat digunakan untuk memenuhi kebutuhan pendidikan anak. Hal ini didukung oleh pendapat (James-burdumy, 2016) bahwa ibu yang bekerja berpengaruh positif dan negatif bagi anak, tidak ada indikasi bahwa pengaruh jangka panjang sama sekali negatif, namun demikian tetap harus ada campur tangan pembuat undang-undang bahwa apakah ibu yang bekerja diizinkan kembali bekerja setelah melahirkan. Temuan ini juga didukung oleh hasil penelitian (Fitria, 2016) mengenai peran ibu yang bekerja terhadap pendidikan anak menunjukkan bahwa anakanak ibu bekerja tetap berprestasi walaupun ibu sibuk bekerja. Hal ini terjadi karena ibu bekerja mencukupkan semua fasilitas penunjang belajar dan memotivasi anak agar tetap berprestasi

Hasil penelitian ini juga menemukan bahwa nilai anak dalam keluarga berpengaruh signifikan terhadap ekspektasi anak. Artinya semakin tinggi nilai anak dalam keluarga maka semakin tinggi ekspektasi ibu tersebut terhadap anak. Sebaliknya semakin rendah nilai anak dalam keluarga maka semakin rendah pula ekspektasi ibu tersebut terhadap anak.

Penilaian atau anggapan ibu akan nilai atau harga seorang anak dalam keluarga akan mempengaruhi perlakuan ibu terhadap anak tersebut. ibu yang menganggap anak berharga akan mengajarkan dan memberikan perlakuan baik kepada anak yang akan berdampak kepada perilaku anak nantinya karena perlakuan tersebut akan menjadi contoh bagi anak dalam bersikap. Ibu yang menilai anak dapat memberikan mamfaat ekonomi dan jaminan hari tua akan mulai memperhatikan pendidikan anak, dengan mencukupi semua kebutuhan anak dan melengkapi fasilitas penunjang pendidikan anak. Hal ini dilakukan dengan harapan anak tersebut dapat memberikan perhatian dan jaminan hari tua sewaktu orang tua tidak lagi mampu mengurus dirinya sendiri dan tidak berpenghasilan lagi. Hal ini didukung oleh pernyataan Kammeyer dalam (Hartoyo, Latifah, \& Mulyani, 2011)bahwa anak dapat menjamin ekonomi orang tua untuk bertahan hidup di usia tua. Selanjutnya (Sunarti, 2008)juga menyatakan bahwa sebagian besar ibu mengharapkan anaknya dapat memberi bantuan ekonomi dihari tua, anak dapat membantu orang tua untuk menyekolahkan adik-adiknya ketika sudah besar dan bekerja, bahkan sejak kecil anak diharapkan dapat 
meringankan beban pekerjaan orang tua, baik pekerjaan di rumah maupun di tempat kerja.

Temuan ini juga didukung oleh hasil penelitian (Hartoyo et al., 2011) yang menyatakan bahwa Ibu yang mengikuti program KB (keluarga berencana) menilai bahwa keberadaan anak akan menjamin keberadaan orang tua di hari tua, dapat memberi hiburan, menghindari kesendirian, menjadikan orang tua lebih bertanggung jawab temuan tersebut menunjukkan bahwa anak dinilai memberikan mamfaat psikologis, ekonomi dan jaminan dihari tua.

Hasil penelitian (Bahri \& Hartoyo, 2013) juga menunjukkan bahwa persepsi orang tua terkait nilai anak juga mempengaruhi perilaku investasi anak yang dilakukan keluarga. Dimana peningkatan skor nilai anak akan menaikkan skor perilaku investasi anak. orang tua akan mengharapkan anak menjadi seseorang yang lebih sukses dan menjaga nama baik keluarga dimasa depan. Hal ini membuat orang tua terutama ibu melakukan perilaku investasi yang baik untuk anak dengan cara memberikan kesempatan kepada anak untuk mendapatkan pendidikan yang lebih baik.

Hasil penelitian lebih lanjut mengenai nilai anak menemukan bahwa rerata nilai anak bagi ibu bekerja lebih tinggi dibandingkan dengan rerata nilai anak bagi ibu tidak bekerja dan uji beda antara keduanya menunjukkan perbedaan yang signifikan. Hal ini berarti ibu bekerja lebih menghargai keberadaan anak dalam keluarga dibandingkan ibu tidak bekerja.

Tingkat pendidikan dan wawasan yang dimiliki oleh ibu bekerja membuat ibu lebih cerdas dalam menanggapi arti seorang anak dalam keluarga. Bagi ibu bekerja, anak bukan hanya sekedar penerus keturunan dan ahli waris yang harus dijaga dan dirawat tetapi anak juga merupakan investasi jangka panjang yang dapat membangkitkan rasa tanggung jawab untuk menjadikan anak sebagai sumber kebanggaan yang dapat memperkuat status sosial orang tua. Ibu bekerja lebih cerdas menanggapi jumlah anak yang harus dimiliki dalam sebuah keluarga. Pengetahuan dan wawasan ibu bekerja tentang kesehatan, pendidikan dan program pemerintah seperti program keluarga berencana (KB) lebih luas. Sehingga ibu bekerja tidak hanya memikirkan harus memiliki anak untuk menunjukkan bahwa ia sempurna namun ibu juga memikirkan bagaimana kelangsungan hidup anaknya kelak dengan memperhitungkan kelangsungan pendidikan, kesehatan, kebutuhan makan dan lain-lain. Dengan anak yang tidak terlalu banyak, perhatian ibu tidak akan banyak terbagi dan ibu lebih mudah mengenal kemampuan serta kepribadian anak-anaknya sehingga ibu akan lebih mudah mengarahkan pendidikan yang cocok untuk anaknya. 
Temuan ini didukung oleh hasil penelitian (Rosidah, Hartoyo, 2012) bahwa bertambahnya lama pendidikan ibu mengikuti pendidikan formal dapat meningkatkan perilaku investasi anak dan perilaku investasi tersebut dipengaruhi oleh persepsi orang tua terkait nilai anak. ibu yang memiliki tingkat pendidikan tinggi dalam penelitian ini merupakan kelompok ibu bekerja yang memiliki rata-rata tingkat pendidikan lebih tingggi dibandingkan ibu tidak bekerja akan lebih memiliki pengetahuan dan kemampuan lebih baik dalam menilai arti keberadaan anak dalam keluarga. (Hartoyo, 1998) juga menyatakan bahwa keluarga dengan pendapatan tinggi akan mencurahkan sumberdaya untuk meningkatkan kualitas anak. keluarga yang memiliki pendapatan tinggi dalam penelitian ini merupakan kelompok ibu bekerja yang memiliki rata-rata tingkat pendapatan lebih tinggi dibandingkan ibu tidak bekerja karena pada keluarga ibu bekerja terdapat dua sumber pendapatan yaitu pendapatan utama dari suami bekerja dan pendapatan tambahan dari ibu bekerja sehingga ada dua sumber pendapatan yang dapat digunakan untuk meningkatkan kualitas anak. Berbeda dengan ibu tidak bekerja yang hanya memiliki satu sumber pendapatan dari suami saya yang dapat dimamfaatkan untuk meningkatkan kualitas anak. Sehingga ibu bekerja yang memiliki rata-rata pendapatan keluarga lebih tinggi akan lebih mudah dalam meningkatkan kualitas anak dibandingkan ibu tidak bekerja.

Temuan ini juga didukung oleh hasil penelitian (Bahri \& Hartoyo, 2013) yang menunjukkan bahwa rata-rata nilai psikologis dan nilai sosial anak bagi keluarga tidak miskin lebih tinggi dibandingkan keluarga miskin dan uji beda antara keduanya menunjukkan perbedaan yang signifikan. Dapat dikatakan bahwa keluarga tidak miskin lebih merasa bahagia, senang, dan puas terhadap terhadap kehadiran anak dalam kehidupannya dan cenderung memiliki persepsi lebih tinggi tentang keuntungan sosial kerena memiliki dan membesarkan anak. Keluarga tidak miskin dalam penelitian ini merupakan kelompok ibu bekerja yang dilihat dari rata-rata tingkat pendidikan dan pendapatannya.

Hasil lain penelitian ini menemukan bahwa literasi keuangan berpengaruh signifikan terhadap ekspektasi anak. Artinya semakin tinggi literasi keuangan maka semakin tinggi ekspektasi ibu tersebut terhadap anak. Sebaliknya, semakin rendah lierasi keuangan maka semakin rendah pula ekspektasi ibu tersebut terhadap anak.

Ibu yang memiliki pengetahuan dan keterampilan dalam mengelola keuangan akan mampu mengalokasikan dana pendidikan anak dengan baik sehingga pendidikan anak dapat berjalan dengan 
lancar. Pengelolaan keuangan dilakukan ibu dengan harapan anak dapat mencapai pendidikan yang lebih tinggi dan menjadi investasi jangka panjang yang dapat ia nikmati dihari tua nanti. Hal ini senada dengan (Byrne, 2013) menyatakan bahwa pengetahuan keuangan yang rendah akan menyebabkan pembuatan rencana keuangan yang salah, dan dapat menyebabkan bias dalam pencapaian kesejahteraan disaat usia tidak produktif lagi.

Sejalan dengan temuan ini sebuah riset di Amerika membuktikan bahwa kemampuan mengelola keuangan melalui literasi keuangan merupakan faktor penting bagi rumah tangga terutama ibu. Karena pengetahuan literasi keuangan mampu membantu ibu rumah tangga merencanakan tabungan, dana pensiun, dana pendidikan, dan rencana investasi (Lusardi \& Mitchell, 2007).

Seorang ibu rumah tangga sudah melakukan estimasi mengenai biaya pendidikan di masa depan dan melakukan evaluasi mengenai perencanaan keuangan pada dana pendidikan anak agar pendidikan yang di jalani dapat berhasil dan harapan ibu terhadap anak lebih mudah dicapai. Ketika seorang ibu mampu mengelola keuangan, ia akan mampu mengalokasikan sumber daya keuangannya sesuai dengan pemanfaatannya demi tujuan yang diharapkan dapat tercapai. Hal ini sesuai dengan pernyataan (Huston,
2010) yang menyatakan bahwa literasi keuangan terjadi ketika individu memiliki sekumpulan keahlian dan kemampuan yang membuat individu tersebut mampu memamfaatkan sumberdaya yang ada untuk mencapai tujuan yang diharapkan.

Hasil penelitian lebih lanjut mengenai literasi keuangan menunjukkan bahwa rerata nilai literasi keuangan ibu bekerja lebih tinggi dibandingkan dengan ibu tidak bekerja dan uji beda antara keduanya menunjukkan perbedaan yang tidak signifikan. Artinya ibu bekerja lebih mampu mengelola keuangan dibandingkan ibu tidak bekerja.

Ketika ibu bekerja, dunia kerja akan menjadikan pola pikirnya lebih terbuka dan wawasan ibu tersebut lebih luas sehingga kemampuan ibu dalam mengelola keuangan keluarga akan lebih baik dan pengelolalan dana pendidikan anak akan lebih mudah. Dengan baiknya pengelolaan keuangan keluarga terutama pengelolalan dana pendidikan anak, ekspektasi akan lebih mudah dicapai. Karena dengan pengelolaan dana pendidikan anak yang baik akan mempermudah anak untuk mendapatkan tingkat pendidikan yang lebih tinggi. Berbeda dengan ibu tidak bekerja yang hanya berada dilingkungan keluarga sehingga pengetahuan dan keterampilannya hanya terbatas disekitar lingkungan keluarga saja membuat kemampuan ibu dalam mengelola keuangan akan terbatas. 
Temuan ini didukung oleh hasil penelitian (Rosaline, 2015) mengenai alokasi pendapatan dan literasi keuangan menunjukkan bahwa ibu bekerja memiliki tingkat literasi keuangan yang lebih tinggi dibandingkan dengan ibu tidak bekerja. Dimana ibu dengan tingkat literasi keuangan tinggi lebih mampu mengalokasikan dana pendidikan anak dibandingkan ibu dengan tingkat literasi keuangan rendah.

\section{KESIMPULAN DAN SARAN}

Peran ibu dalam pendidikan anak, nilai anak dalam keluarga dan literasi keuangan berpengaruh signifikan terhadap ekspektasi anak. Artinya semakin tinggi peran ibu dalam pendidikan anak, semakin tinggi nilai anak dalam keluarga dan semakin tinggi kemampuan ibu dalam mengelola keuangan maka semakin tinggi ekspektasi ibu tersebut terhadap anak.

Dalam pendidikan anak, peran ibu bekerja lebih tinggi jika di bandingkan dengan ibu yang tidak bekerja. Hal ini berarti ibu bekerja bisa menyeimbangkan perannya sebagai ibu keluarga dan wanita pekerja. Serta dapat memanfaatkan peran ganda tersebut untuk kepentingan pendidikan anak dibandingkan ibu tidak bekerja yang hanya mengurus keluarga. Nilai anak bagi ibu bekerja lebih tinggi jika di bandingkan dengan ibu tidak bekerja. Hal ini berarti ibu bekerja lebih menghargai arti keberadaan anak dalam keluarga dibandingkan ibu tidak bekerja. Literasi keuangan ibu bekerja lebih tinggi jika di bandingkan dengan ibu yang tidak bekerja. Hal ini berarti ibu bekerja lebih mampu mengelola keuangannya dibandingkan ibu tidak bekerja.

Dalam mencapai ekspektasi terhadap anak para ibu disarankan untuk lebih meningkatkan perannya dalam pendidikan anak terutama dalam menyediakan fasilitas belajar dan menasehati anak untuk lebih giat belajar agar berprestasi. Para ibu disarankan untuk lebih meningkatkan penilaiannya akan arti penting keberadaan anak dalam keluarga terutama arti penting anak yang dapat membangkitkan rasa tanggung jawab orang tua dan anak dapat menjadi sumber kebanggaan bagi orang tua. Serta para ibu disarankan untuk lebih meningkatkan kemampuannya dalam mengelola keuangan dimana ibu harus mulai membuat tabungan pendidikan anak dan mulai berinvestasi untuk rencana keuangan jangka panjang.

\section{DAFTAR PUSTAKA}

Attitudes, C., Demİrcİoğlu, H., \& Ömeroğlu, E. (2014). Effect of Training from Trained Mothers and Education from Mother to Mother on Family Functions and, 14(4), 1456-1465. https://doi.org/10.12738/estp.2014.4.21 14

Bahri, N. M., \& Hartoyo, H. (2013). Perilaku Investasi Anak pada Keluarga Miskin dan Tidak Miskin. Jurnal Ilmu Keluarga Dan Konsumen, 6(3), 190- 
198.

https://doi.org/10.24156/jikk.2013.6.3.1 90

Behrman, J. R., Mitchell, O. S., Soo, C. K., Bravo, D., The, S., Economic, A., ... Hastings, J. (2015). American Economic Association How Financial Literacy Affects Household Wealth Accumulation OF FINANCIAL EDUCATION AND FINANCIAL LITERACY * How Financial Literacy Affects Household Wealth Accumulation1, 102(3).

Byrne, A. (2013). Employee Saving and Investment Decisions in Defined Contribution Pension Plans: Survey Evidence from the UK. Journal of Chemical Information and Modeling, 53(9), 1689-1699. https://doi.org/10.1017/CBO978110741 5324.004

Cude, B. J., Lawrence, F. C., \& Agcenter, L. S. U. (2006). College Students and Financial Literacy: What They Know and What We Need to Learn, 102-109.

Dwiastanti, A. (2015). Financial Literacy as the Foundation for Individual Financial Behavior, 6(33), 99-105.

Fenomena, A., Kecamatan, M., Kabupaten, K., Utara, M., Komunikasi, I., \& Remaja, K. (2015). Journal "Acta Diurna" Volume IV. No.1. Tahun 2015, $I V(1)$.

Fitria, D. (2016). Peran Ibu Yang Bekerja Terhadap Pendidikan Anak. Ilmu Sosiologi.

Georgiou, S. N. (2007). Parental involvement: beyond demographics. International Journal about Parents in Education, 1(0), 59-62.
Gregg, P., Washbrook, E., Propper, C., \& Burgess, S. (2005). THE EFFECTS OF A MOTHER' S RETURN TO WORK DECISION ON CHILD DEVELOPMENT IN THE UK *, 115.

Gunarsa, S. . (2006). Page 1. Jakarta: Gunung Mulia.

Hartoyo. (1998). Investing In Children: Study Of Rural Families In Indonesia. Faculty of the Virginia Polytechnic Institute and State Univesity in Partial Fulfillment of the Requirements for the Degree of.

Hartoyo, Latifah, M., \& Mulyani, S. R. (2011). Studi Nilai Anak, Jumlah Anak yang Diinginkan, dan Keikutsertaan Orang Tua dalam Program KB. Jurnal Ilmu Keluarga Dan Konsumen, 4(1), 37-45.

Hoffman, L. W., Thornton, A., \& Jean, D. (1978). The Value of Children to Parents in the United States, 1(2).

Hoover-dempsey, K. V, \& Sandler, H. M. (1997). Review of Educational Research. https://doi.org/10.3102/0034654306700 1003

Huston, S. J. (2010). Measuring Financial Literacy. Journal of Consumer Affairs, 44(2), 296-316. https://doi.org/10.1111/j.17456606.2010.01170.x

James-burdumy, S. (2016). The Effect of Maternal Labor Force Participation on Child Development, 23(1), 177-211.

Knaack, A. (2003). Effortful Control as a Personality Characteristic of Young Children: Antecedents, Correlates, and Consequences, (December 2003). 
Kochanska, G., \& Clark, L. A. (n.d.). (1997). Implications of Mothers ' Personality for Their Parenting and Their Young Children's Developmental Outcomes, (June 1997).

Lusardi, B. A., \& Mitchell, O. S. (2007). Financial Literacy and Retirement Prepared- ness : Evidence and, (January), 35-44.

Lyons, A. C. (2004). A Profile of Financially At-Risk College Students, 38(1), 56-80.

Marina, P., Prof, A., Todorovic, J., \& Dragana, A. (2014). Patterns of Family Functioning and Dimensions of Parenting Style. Procedia - Social and Behavioral Sciences, 141, 431-437. https://doi.org/10.1016/j.sbspro.2014.05 .075

Nov, N., Joyce, B. B., \& Weil, M. (2014). Models of Teaching by Bruce Joyce; Marsha Weil Models of Teaching, 82(1), 147-154.

Petrie, J. T., \& Holloway, S. D. (1997). Mothers ' Representations of the Role of Parents and Preschools in Promoting Children's Development, (1995).
Rosaline, G. A. (2015). Literasi Keuangan dan Alokasi Pendapatan (Studi Empiris Pada Ibu Rumah Tangga di Kelurahan Panggung Lor, Kecamatan Semarang Utara Kota Semarang). EKONOMI BISNIS, (September).

Rosidah, Hartoyo, M. (2012). Kajian Srategi Koping dan Perilaku Investasi Anak Pada Keluarga Buruh Pemetik Melati Gambir. Departemen Ilmu Keluarga dan Konsumen Fakultas Ekologi Manusia Institut Pertanian Bogor.

Sunarti, E. (2008). Keragaman Pemetik Teh Wanita : Sosial Ekonomi, Ketahanan Keluarga, Konsumsi. Journal Human Ecology, 1-7.

Yazdani, S., \& Daryei, G. (2016). Paci fi c Science Review B : Humanities and Social Sciences Parenting styles and psychosocial adjustment of gifted and normal adolescents. Pacific Science Review A: Natural Science and Engineering, 2(3), 100-105. https://doi.org/10.1016/j.psrb.2016.09.0 19 